ZOOLOGIA 30 (4): 379-387, August, 2013

http://dx.doi.org/10.1590/S1984-46702013000400003

\title{
Selection of habitat by the jaguar, Panthera onca (Carnivora: Felidae), in the upper Paraná River, Brazil
}

\author{
Laury Cullen Junior ${ }^{1,3}$, Dênis A. Sana ${ }^{2}$, Fernando Lima ${ }^{1}$, Kauê C. de Abreu ${ }^{1} \&$ Alexandre Uezu ${ }^{1}$ \\ 1 Programa em Biologia da Conservação, IPÊ - Instituto de Pesquisas Ecológicas. 12960-000 Nazaré Paulista, SP, Brazil. \\ 2 Projeto Onça Pintada, Pro-Carnívoros - Instituto para a Conservação de Carnívoros Neotropicais. 12945-010 Atibaia, SP, Brazil. \\ ${ }^{3}$ Corresponding Author: Email: Icullen@stetnet.com.br
}

\begin{abstract}
We used data from VHF and GPS radio-tagged jaguars, Panthera onca (Linnaeus, 1758) to quantify jaguar habitat selection and how adult individuals in the Upper Paraná River region selected among the available habitat types. We followed the framework in which animals make decisions about resource use at hierarchical stages, namely selection of home range within a study area (second-order selection) and selection of patches within a home range (third-order selection). We quantified habitat preferences at two orders of selection with respect to habitat types and to test the null hypothesis that habitat utilization by jaguars was random at both study sites. Using compositional analysis, we assessed habitat selection by jaguars at second- and third-orders of selection. Jaguars consistently preferred dense marshes and primary forests, and avoided human-dominated areas such as intensively managed open pastures. Although the avoidance of disturbed and developed habitat types by jaguars is not surprising, this is the first study to document it. If small protected areas, such as the ones already existing in the Upper Paraná region, are to sustain jaguar populations they, must include and protect as many primary forests and marshlands as possible, so that jaguars can disperse, hunt wild prey and take care of their cubs without being disturbed. What is urgently needed in these jaguarprotected areas is the creation of larger protected areas that can sustain jaguars in their favored habitat.

KEY WORDS. Habitat preference; GPS and VHF telemetry; compositional analysis; large predator; Neotropical felid guild.
\end{abstract}

In Brazil, quantitative information on habitat selection by jaguars, Panthera onca (Linnaeus, 1758), is rare. One of the few available sources of this kind of data was collected in seasoned flooded environments of the Pantanal (CAVALCANTI \& GeSE 2009). The once extensive jaguar habitat of the Atlantic Forest has been drastically fragmented and degraded, and today only about $16 \%$ of its natural habitat remains (Ribeiro et al. 2009). Understanding jaguar habitat selection is relevant to mitigating the impact of hunting and trapping of jaguars, jaguar attacks on cattle (Crawshaw 2004), habitat fragmentation (CULLEN et al. 2005), and for developing habitat suitability models for large scale conservation (АКÇAKAYA 2004)

A number of previous studies have emphasized the importance of landscape patterns and habitat selection in species conservation (Coppolilli et al. 2004, Haines et al. 2006, KARANTH et al. 2011). Large carnivore species such as the jaguar may require more than just large areas for their survival. Some species need certain habitat or habitat types, and resources during their life cycle. These particular resources should be protected, as well as their configuration, to allow jaguars to establish their home range and to move among habitat types. The Upper Paraná River is a very heterogeneous and semi-connected landscape, which requires an evaluation of the composition and connectivity of the landscape elements and how jaguars select among these different habitats. We attempted to identify habitat patchiness from the jaguar's perspective, and to understand how the species perceives the patchiness of the landscape.

Although some aspects of jaguar ecology have been previously investigated across the species' range (Quigley \& Crawshaw 1992, Crawshaw et al. 2004, Colchero et al. 2011), these studies failed to assess habitat selection quantitatively. Long-term studies on the species in Latin America have concentrated in home range analysis (Rabinowitz \& NotTingham 1986, Crawshaw \& Quigley 1991), diet and prey base (CrawshaW et al. 2004, Polisar et al. 2003, WeCKel et al. 2006, CavalCanti \& GeSE 2012) and attacks on livestock (Polisar et. al. 2003, Azevedo 2008, Hoogesteijn \& Hoogestejn 2008).

In this study we used data from VHF and GPS radio-tagged jaguars to quantify how adult individuals in the Upper Paraná River region selected among the available habitat types. We followed the framework developed by Johnson (1980) and AEBischer et al. (1993), in which animals make decisions about resource use at hierarchical stages, namely selection of home range within a study area (second-order selection) and selection of patches within a home range (third-order selection). First-order selection (selection species geographic range) was beyond the scope of this study. Our main objective was to quan- 
tify habitat preferences at two orders of selection with respect to habitat types and to test the null hypothesis that habitat utilization by jaguars was random at both study sites.

\section{MATERIAL AND METHODS}

This study was carried out in the Morro do Diabo State Park (MDSP), state of São Paulo, and Ivinhema State Park (ISP), state of Mato Grosso do Sul. The MDSP has 37,000 ha and is located in the Pontal do Paranapanema, a wedge-shaped region bounded to the north by the Rio Paraná and to the south by the Rio Paranapanema, and corresponds to the western portion of the state of São Paulo $\left(22^{\circ} 30^{\prime} \mathrm{S}, 52^{\circ} 20^{\prime} \mathrm{W}\right)$. It is the last significant remnant of Atlantic forest in the west of São Paulo state, where only $1.8 \%$ of the original natural habitat remains The forests of Morro do Diabo are considered a transitional ecosystem, bordered by tropical evergreen broadleaf forest to the east, which originally covered the Atlantic coastline, and the dry cerrado vegetation to the north and west (AB'SABER 1977). The ISP has 73,000 ha and is located $150 \mathrm{~km}$ southwest of Morro do Diabo in the south-eastern corner of the state of Mato Grosso do Sul, and comprises several former cattle ranches. The landscape can be characterized as a complex mosaic of interdigitated forest patches and open areas, with habitat types based on the interaction of elevation, substrate, hydrology and past perturbations, such as logging and fire. The main habitat types in ISP are seasonally flooded savannas (dense and open marshes), seasonally flooded semi-deciduous forests (alluvial forests), dry hillside savannas, dry hillsides cerrados,semi-deciduous dry forests, gallery forests, and abandoned pastures. In both study areas the climate is markedly seasonal, and most of the $1,450 \mathrm{~mm}$ of yearly precipitation falls between early October and late March.

Between April 2000 and August 2007, 10 adult jaguars (> 2 years old) were captured, radio-collared, and monitored, seven at Morro do Diabo State Park (MDSP) and three at Ivinhema. We analyzed habitat selection separately for the dry season (April-September), the wet season (October-March), and for both periods combined. We use the term "annual" to indicate analysis using data for dry and wet seasons combined. A dry season includes locations for one or more dry seasons across all years an individual was studies. All jaguar locations were plotted on a Landsat Satellite Image.

Topographic map layers and habitat categories included variables most likely to explain jaguar spatial distribution. The term habitat was used for a layer of the proportions of a habitat class defined by habitat type or other classifying factors, and is used by, or is available for an animal to use. Each habitat composition for the study area sums up to $100 \%$. To account for error in assigning an individual radio-location to a particular habitat type, the analysis assumed that a jaguar used all habitat types within a $100 \mathrm{~m}$ radius of a radio-location in proportion to the availability of habitat types within the circle.
This study followed RetTie \& McLoughuIN (1999), according to whom, although the use of point data increases the probability of rejecting the null hypothesis of random habitat use, the use of point buffers will reduce the likelihood of drawing erroneous conclusions about relative preference. To evaluate second-order selection, we compared the habitat composition of the study area with the habitat composition of individual jaguar radio-locations. For third-order selection, we compared the habitat composition of an individual's yearly fixed-kernel $85 \%$ home range with the habitat composition of the radio-locations of that individual during its yearly fixed-kernel $85 \%$ home range.

At both scales of selection, we used compositional analysis to develop a ranking of habitat preference (Aitchison 1986, Aebischer \& Robertson 1992, Aebischer et al. 1993). Compositional analysis uses the individual animal rather than the radio-location as the sampling unit, and avoids statistical problems arising from non-independence of proportions within a habitat composition (AEBISCHER et al. 1993). Because compositional analysis uses estimated habitat proportions rather than point data, the error and bias inherent in telemetry locations can be accommodated (RetTIE \& McLoughlin 1999).

At both levels of analysis, we considered only those habitat classes available to all jaguars. Compositional analysis compares use of each habitat class to an arbitrary reference class $k$ by the log-transformed ratio of habitat proportions for each animal (Aitchison 1986): $y_{i j}=\ln \left(x_{i j} / x_{i k}\right)(i=1, \ldots, n ; j=1, \ldots, D ; j$ “" $k$ ), where $x_{i j}$ describes an individual $i$ 's proportional use of the $\mathrm{j}$-th of $D$ habitat types and $n$ is the number of individual animals. When an individual's proportional utilization of a habitat was 0 , we replaced this value with a number less than one-tenth of the smallest observed value for that habitat (Aebischer et al. 1993). The differences between used and available habitat log-ratios for each individual formed a single row of a difference matrix with $n$ rows and $D-1$ columns. To test the null hypothesis that utilization was random (difference matrix $=0$ ), we constructed a residual matrix from the matrix of log-ratio differences and computed Wilk's lambda statistic, $\Delta$, where: $\Delta=\% R 1 \% / \% R 2$, and where $R 1$ is the matrix of mean corrected sums of squares and cross-products and $R 2$ is the matrix of raw sums of squares and cross-product. Following the procedure proposed by AEBISCHER et al. (1993), we transformed $\Delta$ into the test statistic: " $n$. $\ln (\Delta)$, which approximates a Chi-square distribution with $D 1$ degrees of freedom and where $n$ is the number of individuals in the sample and $D$ is the number of habitat classes. When habitat use was significantly nonrandom ( $\mathrm{p}<0.05)$, we calculated the mean and standard deviation for all log-ratio differences and constructed a matrix ranking of habitat types in their order of use.

To assess differences between ranks, we used a paired $t$ test to compare mean utilization between all pairs of habitats.

The vegetation cover of the Upper Paraná River region (including the MDSP and ISP) was analyzed digitally from 2002- 
2003 LandSat Images, using both ground knowledge and unsupervised classification of the three Landsat 7ETM satellite images that encompassed both study areas. The analysis was done with Erdas Imagine 8.4 and Arcview 3.3/Spatial Analyst. All habitat types were categorized and classified. Initially, we identified 16 broad vegetation types and interpolated these across the two study areas. We further consolidated infrequent habitat types into eight more general vegetation or habitat types (Table I and Fig. 1). Lakes, rivers, and man-made watercourses were classified as water. Vegetation map layers and habitat categories included those most likely to explain jaguar habitat selection and those that composed the majority of the Upper Paraná River mosaic.

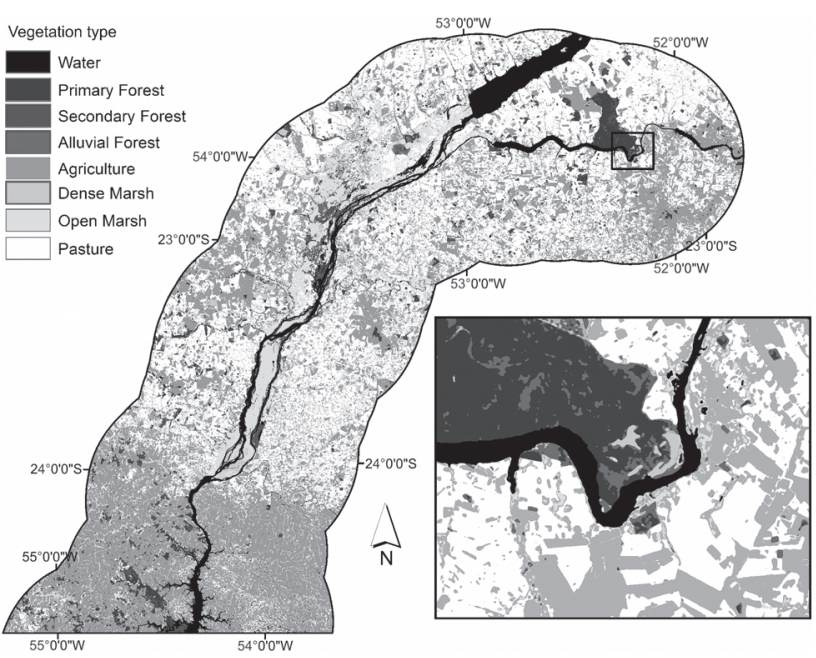

Figure 1. The eight habitat types used in the analysis of habitat selection by jaguars in the Upper Paraná River study area.

\section{RESULTS}

\section{Habitat selection in Morro do Diabo State Park}

Within the Morro do Diabo study area, the pre-dominant habitat types were pasture (50\%), agriculture (17\%) and primary forest $(15 \%)$. Open marshes and dense marshes were less dominant ( $6 \%$ and $1 \%)$, whereas alluvial forests were very rare $(0.05 \%)$ (Table I). In this area, jaguars selected dense marshes and primary forests and avoided human-dominated areas such as agriculture and pasture at both second-order scale, for radio-locations within the study area, and third-order scale, for radio locations within a home range (Figs 2-4). At the second order, proportional use of habitat types of the study area differed from habitat composition of the study area between seasons (Chi-square test, $\mathrm{p}<0.05, \mathrm{n}=2$ males and 5 females), and in the dry season ( $\mathrm{p}<0.05, \mathrm{n}=2$ males and 5 females), but did not differed in the wet season $(\mathrm{p}>0.05, \mathrm{n}=2$ males and 3 females). Both within and between seasons, jaguars consistently preferred dense marshes and avoided disturbed areas. The rank order of habitat types selected by jaguars varied slightly between seasons, as did the statistical significance of pairwise comparisons. Developed, disturbed, and agricultural habitat types were consistently avoided.
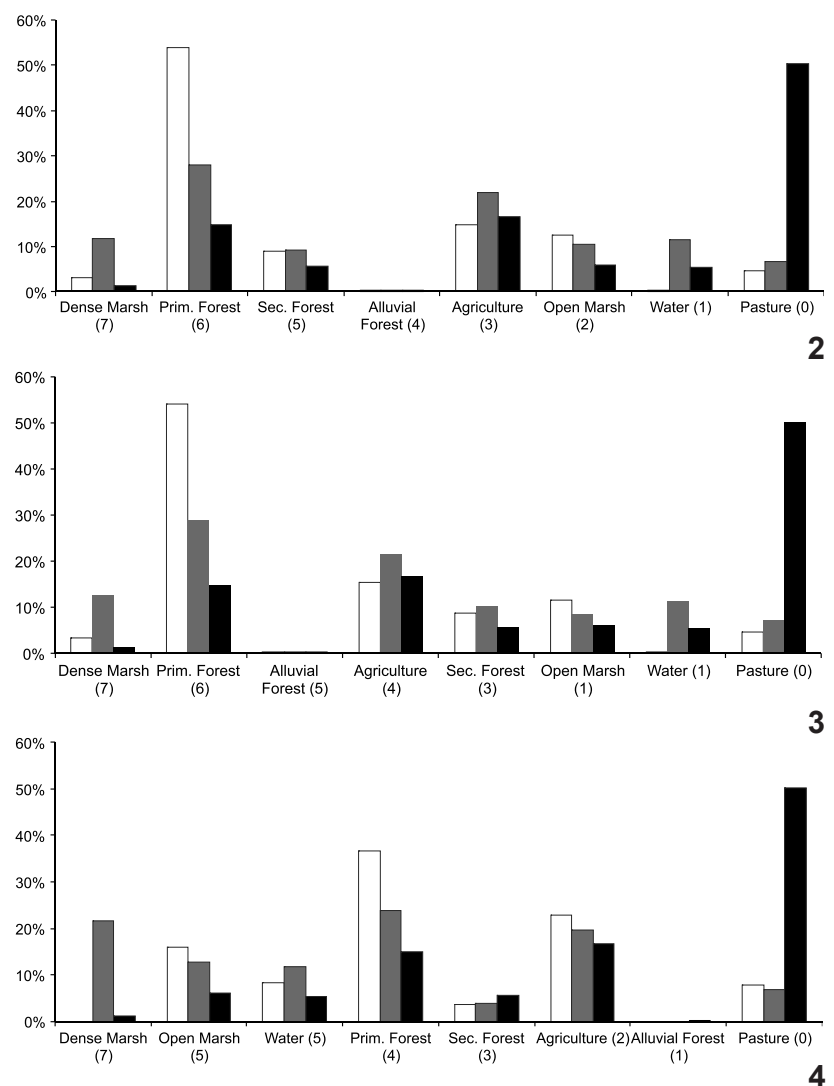

Figures 2-4. Second-order selection by jaguars in the Morro do Diabo study area. Habitat types are arranged from most to least preferred for (2) seasons combined, (3) dry season, (4) wet season. White bars indicate mean female utilization, gray bars indicate mean male utilization, and black bars indicate habitat availability. Numbers of habitat types on the $\mathrm{x}$-axis indicate rank of preference for the habitat types.

In assessing third-order selection, we eliminated the habitat class "water" from the compositional analysis, because it was available to only a few individuals. For third-order selection, the habitat composition of an individual's yearly $85 \%$ home range (HR) was compared to the habitat composition of the radio locations of that individual obtained in its yearly $85 \%$ home range. Use of habitat types within multi-year (i.e., polled data across years for each individual) $85 \%$ home ranges did not differ from availability in the dry season (Chi-square test $\mathrm{p}>0.05,2$ males and 5 females), in the wet season ( $\mathrm{p}>$ 
0.05, 2 males and 3 females) and between seasons ( $p>0.05,2$ males and 5 females) (Figs 5-7). However, in all cases, primary forest was the most preferred habitat among all seasons. When pasture and alluvial forests occurred within a jaguar's home range, they were generally used in lower proportions than their spatial availability. At both orders of scale (second- and thirdorder), males and females preferred primary forest and were very consistent in their rank of preference of habitat types (Figs $5-7)$.

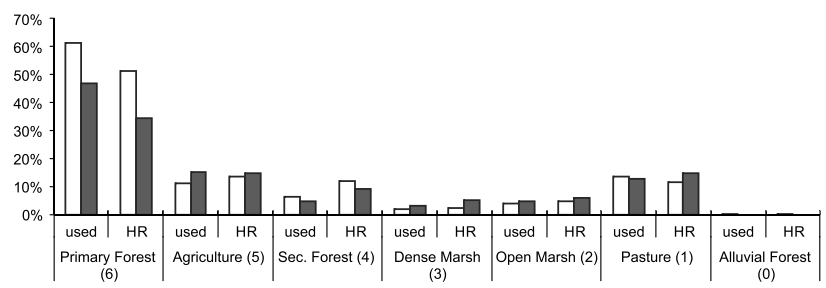

5

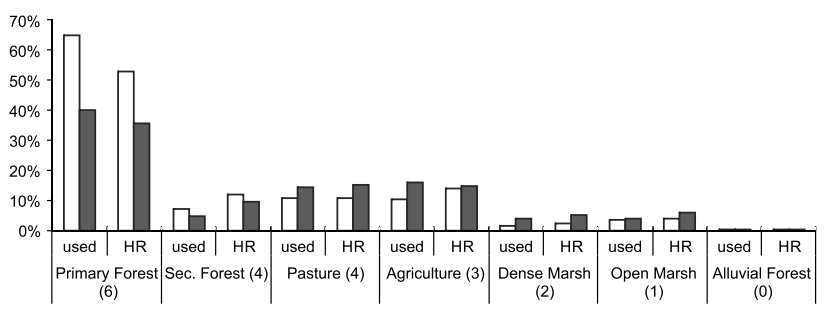

6

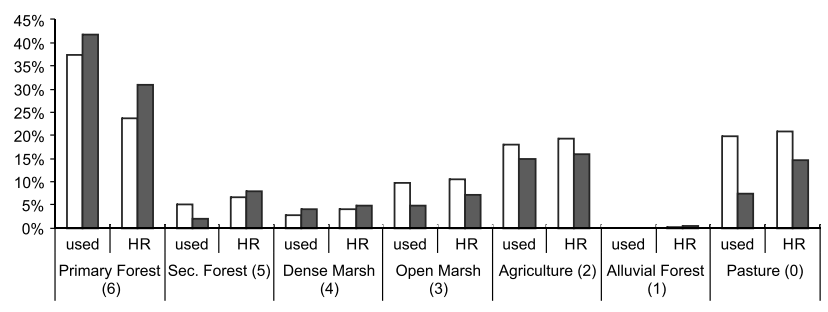

7

Figures 5-7. Third-order selection by jaguars in the Morro do Diabo study area. Habitat types are arranged from most to least preferred for (5) seasons combined, (6) dry season, (7) wet season. White bars indicate mean female utilization; gray bars indicate mean male utilization. Numbers of habitat types on the $\mathrm{x}$-axis indicate rank of preference vegetation.

\section{Habitat selection in Ivinhema State Park}

Within the Ivinhema study area, the dominant habitat types were pasture (50\%), open marsh (18\%) and agriculture (14\%). Dense marshes and secondary forests were scarce $(4 \%$ and $3 \%$, respectively) whereas primary forests were very rare (1\%) (Table I). In this area, jaguars selected dense marshes and open marshes and avoided primary forests at the second-order scale (radio-locations within the study area). At the second order, proportional use of habitat types on the study area did not differ from habitat composition of the study area between seasons (Chi-square test $\mathrm{p}>0.05, \mathrm{n}=1$ male and 2 females), dry season ( $\mathrm{p}>0.05, \mathrm{n}=1$ male and 2 females) and wet season $\mathrm{p}>0.05, \mathrm{n}=1$ male and 2 females) (Figs 8-10). Again, dense marsh was the most preferred habitat among all seasons. The rank order of habitat types selected by jaguars varied slightly between seasons, as did the statistical significance of pairwise comparisons. Open water and primary forests were consistently avoided by jaguars.
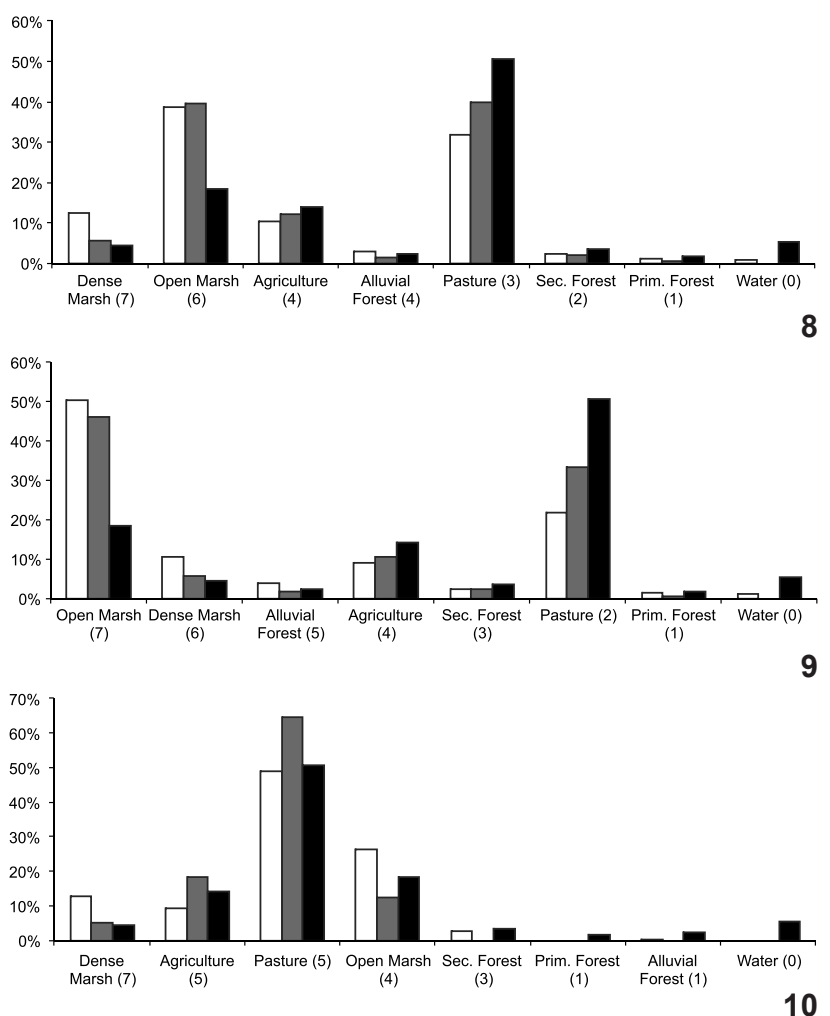

Figures 8-10. Second-order selection by jaguars in the Ivinhema study area. Habitat types are arrayed from most to least preferred for (8) seasons combined, (9) dry season, (10) wet season. White bars indicate mean female utilization; gray bars indicate mean male utilization; and black bars indicate habitat availability. Numbers of habitat types on the $\mathrm{x}$-axis indicate rank of preference vegetation types.

For third order scales, the use of habitat types on multiyear $85 \%$ home ranges differed from availability between seasons ( $\mathrm{p}<0.05,1$ male and 2 females), but not for the wet season ( $p>0.05,1$ male and 2 females) nor for the dry season ( $p>0.05$, 1 males and 2 females). Both within and between seasons, jaguars consistently preferred open marshes and abandoned pastures with some livestock maintenance, and avoided primary and secondary forests. The rank order of habitat types selected 
by jaguars varied slightly between seasons as well as the statistical significance of pairwise comparisons (Figs 11-13).
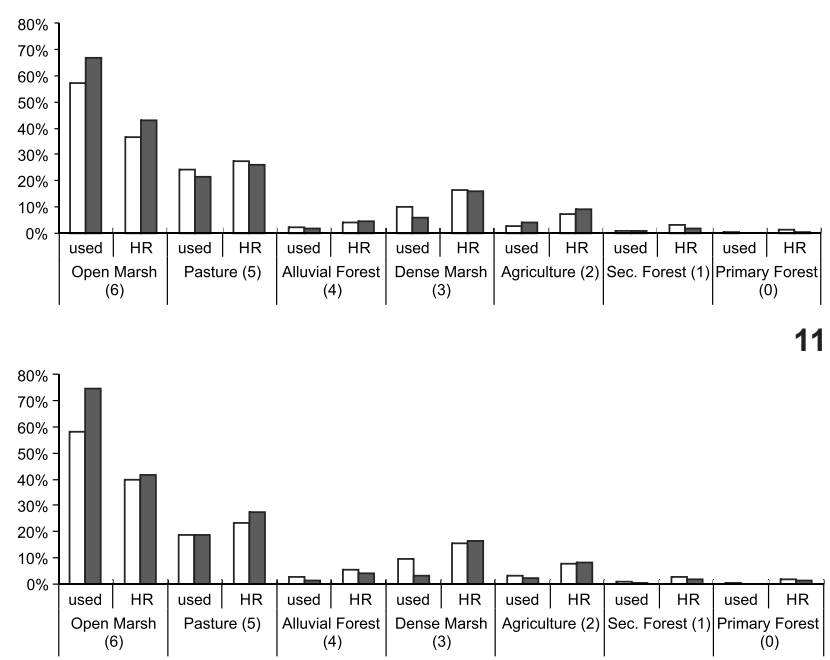

12

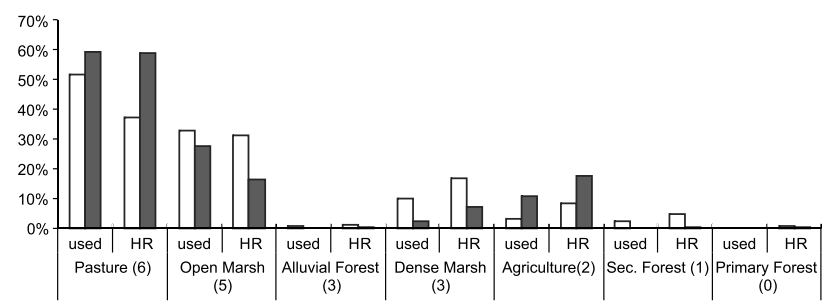

13

Figures 11-13. Third-order selection by jaguars in the Ivinhema study area. Habitat types are arrayed from most to least preferred for (11) seasons combined, (12) dry season, (13) wet season. White bars indicate mean female utilization; gray bars indicate mean male utilization. Numbers of habitat types on the $\mathrm{x}$-axis indicates rank of preference vegetation.

\section{DISCUSSION}

Few studies have investigated habitat selection of jaguars, and those that reported habitat use by jaguars have not documented habitat selection at the fine scale described in this study, with the use of modern GPS telemetry. However, the habitats selected in this study were consistent with those documented elsewhere, in that jaguars show a strong affinity for dense and well watered lowlands and primary forests. In this study, jaguars in general preferred dense marshes and avoided human-dominated areas such as intensively managed open pastures. At second and third-order scale, alluvial forests and pastures were consistently the most avoided habitat types in both study sites. Our results are similar to findings by LogAn \& IRwiN (1985) and Williams et al. (1995), and the avoidance of open habitats may be due the lack of cover, as it has been suggested for cougars. Although the aversion of disturbed and developed habitat types by jaguars is not surprising, this study is the first to document such avoidance.

In the Morro do Diabo, where jaguars preferred forest habitats, the use of aquatic environments such as open water, dense and open marshes seemed to increase in the wet season, whereas the use of forested environments (primary forest and secondary forest) decreased. A similar trend was observed at the third order scale. In ISP, jaguars significantly avoided forested environments, which occur in very low proportions. During the wet season, jaguars increasingly made use of higher elevations, apparently preferring dry and abandoned pastures with some livestock.

The close association of jaguars with water has long been described by naturalists and explorers (Roosevelt 1914, Miller 1930, Perry 1970). As reported in this study, the species shows a preference for terrain close to rivers, streams, and dense marshes (Guggisberg 1975, Mondolfi \& Hoogesteijn 1986, Bisbal 1989). SolLmann et al. (2012) showed that jaguars have higher occupancy probabilities in habitats near water and in dense

Table I. Habitat types in the Morro do Diabo State Park and in the Ivinhema State Park studies areas used for habitat selection analysis by jaguar.

\begin{tabular}{|c|c|c|c|c|}
\hline \multirow[b]{2}{*}{ Habitat Type } & \multicolumn{2}{|c|}{ Morro do Diabo State Park } & \multicolumn{2}{|c|}{ Ivinhema State Park } \\
\hline & Total $\mathrm{km}^{2}$ & $\begin{array}{c}\text { Proportional habitat } \\
\text { availability }(\%)\end{array}$ & Total $\mathrm{km}^{2}$ & $\begin{array}{c}\text { Proportional habitat } \\
\text { availability (\%) }\end{array}$ \\
\hline Water & 110 & 5.33 & 186 & 5.28 \\
\hline Primary Forest & 307 & 14.88 & 59 & 1.70 \\
\hline Secondary Forest & 116 & 5.66 & 119 & 3.38 \\
\hline Alluvial Forest & 1 & 0.05 & 80 & 2.29 \\
\hline Dense Marsh & 25 & 1.25 & 153 & 4.34 \\
\hline Open Marsh & 124 & 6.02 & 644 & 18.30 \\
\hline Agriculture & 342 & 16.58 & 493 & 14.00 \\
\hline Pasture & 1036 & 50.20 & 1785 & 50.68 \\
\hline Total & 2064 & 100.00 & 3522 & 100.00 \\
\hline
\end{tabular}


vegetation, as opposed to open grasslands in the Cerrado. Even when jaguars use open, dry areas, they always seek cover in nearby dense habitat (Mondolfi \& Hoogesteijn 1986, Rabinowitz \& NotTinghan 1986). As reported by Crawshaw \& Quigley (1991) in the Miranda Ranch in the Pantanal, jaguars were rarely found far from water and used dense marshlands and gallery forests more often than expected on the basis of their availability. In Morro do Diabo, the areas with less prey are those of dry open "cerrados" in the far north of the study area (Cullen et al. 2001). The same occurs for the dry pastures that are used for livestock in Ivinhema. These pastures are bordered by the dry forest, a habitat more frequently occupied by the puma.

Contrary to earlier assessments, jaguars in the Upper Paraná region do not appear to be closely associated with forested environments (primary and secondary forests). This is specifically the case of jaguars living in the Ivinhema area, where both types of forests ranked very low in habitat preference. The distribution of semideciduous forests in this ecosystem has decreased dramatically due to repeated fires and intensive logging over the past century. Jaguar distribution was probably more closely associated with dense forests prior to these disturbances. However, jaguars have persisted since the Atlantic forests have been deforested, suggesting that jaguars are not solely dependent on dense forest types. Today, dense and open marshes that comprise only about $15 \%$ of the Upper Paraná landscape are the main habitats for the remaining jaguar populations.

In this study, dense marshes along riparian vegetation ranked first in use by the jaguar, but several other associated habitat types were also important. The ecotones of habitat types that create productive edges seem to be a key factor in defining desirable jaguar home ranges both in Morro do Diabo and Ivinhema. Thus, the situation for the jaguar may be similar to that of the tiger, which prey is most abundant where grasslands, dense marshlands and forests form a mosaic, and the interdigitation of many different habitat types supports a rich ungulate community (SUnQuist et al. 1999, KARANTH et al. 2011). This same situation was observed by Polisar et al. (2003) in the llanos of Venezuela, where prey abundance and jaguar habitat use was intense in lowland dense marshlands and well-watered forest-savanna habitats. The attraction of other carnivores to prey-rich lowland forest-marshland ecotones has also been noted in other studies of large predator species (Palomares et al. 1996, Durant 1998, Cavalcanti \& Gese 2010, Gomez et al. 2010).

In the Upper Paraná River, especially in the region of Ivinhema and Ilha Grande National Park, further to the south, the marsh deer Blastocerus dichotomus (Illiger, 1815) is an important prey item in the jaguar's diet and this species prefers riparian areas and dense marshes. In 2002, an aerial survey was conducted to estimate the population size and the abundance of marsh deer throughout the Upper Paraná River floodplain, using the double count method. The population was estimated at 1,079 \pm 207 individuals for $1,081 \mathrm{~km}^{2}$, which gives a density of $0.998 \pm 0.192 \mathrm{deer} / \mathrm{km}^{2}$ and an estimated biomass of $120 \mathrm{~kg} / \mathrm{km}^{2}$. This estimate is the greatest reported for the species in Brazil (Schaller \& Vasconcelos 1978, Mourão \& CamPOS 1995, PINDER 1996).

The use of dense marshes adjacent to riparian areas and forest patches is likely to enhance the jaguar's ability to stalk and kill prey, including the marsh deer. In both Morro do Diabo and Ivinhema, these ecotones should provide good stalking cover and ambush sites (vegetation height typically $<1.5 \mathrm{~m}$ ). Riparian areas in major drainages should also provide important movement corridors for jaguars, associated with travel paths, as indicated by the fact that most home ranges of jaguars in Morro do Diabo are associated with the Paranapanema River. Undoubtedly, the dense marshes bordered by the riparian areas provide important stalking and feeding cover for the Upper Paraná River jaguar populations.

The second and third-order selection of jaguars should correspond to selection of habitat parameters that normally relate to prey distribution. At the third order scale, an animal should attempt to include within its home range those parameters that increase the potential for reproductive success. Indeed, jaguars in both Morro do Diabo and Ivinhema, at third order scale, seemed to select home range locations that corresponded with habitat types that differed from the second order scales. At the third order selection, the core areas where jaguars were found were places where prey seemed to be more abundant. For example, in the Morro do Diabo area, jaguars selected marshlands at the second order selection and primary forests at third order, where ungulate density is high (CULLEN et al. 2001). In Ivinhema, jaguars selected dense and open marshes at the second order, and upland areas such as pastures at the third order, where cattle ranching was intense.

\section{Implications for jaguar conservation}

Our field reports have also found supporting evidence that cattle predation by jaguars seemed to increase in the wet season at the Ivinhema State Park, when jaguars increasingly selected higher elevations, apparently preferring dry and abandoned pastures with some livestock for prey. The move to higher elevations in the wet season is also explained by the inundation of the lowland areas with higher precipitation. These results have important management implications. For example, efforts in field monitoring and farmer outreach should be prioritized in the rainy season, because in the rainy season jaguars concentrate their range in higher areas where farmers have cattle. In these areas, cattle predation by jaguars will increase in the rainy season and conflicts with land owners may emerge.

Jaguars showed preference for dense and open marshes in these study areas, and this has important implications for the conservation of the species. Combined, dense and open marshes still comprise approximately $15 \%$ of the analyzed landscape. These marshes are the only potential jaguar habitats 
that continuously connect the remaining protected areas along the Paraná River basin. Marshes are still in good condition along the Paranapanema River, downwards to the Paraná River, connecting the Morro do Diabo to the Ivinhema State Park, and Ivinhema to other protected areas nearby. These productive marshlands may facilitate natural dispersal and allow genetic exchange among jaguar subpopulations. As marshlands are among the habitats preferred by jaguars, and connectivity is needed for metapopulation conservation (Hanski \& Simberloff 1996), our results highlight the urgent need for marshland conservation.

The selection of marsh habitats indicates that the jaguar populations that appears to be fragmented and isolated could be linked by their preferred habitats, revealing the existence of potential marshland corridors and habitat linkages that were not readily apparent. In a simulation of cougar populations, BEIER (1993) showed that immigration into a small population of one to four animals during a decade can significantly increase persistence. Similarly, persistence of jaguar populations in the Upper Paraná River can be enhanced if these populations can be managed as a metapopulation. Maintaining these habitats before they become totally converted is important for landscape conservation and jaguar metapopulation management. This priority is well supported by (HAAG et al. 2010) indicating that jaguars' ability to effectively disperse across human-dominated landscapes is currently very limited, and that each fragment contains a small, isolated population that is already suffering from the effects of genetic drift.

When third order selection is analyzed, the core areas of jaguars were upland and pasture, where private cattle ranching are intense. Conflicts with farmers are common because of cattle predation. The long-term survival of jaguar subpopulations is dependent on the movement of dispersing jaguars between habitat patches. If dispersal is hampered, because of such low quality population sinks, subpopulations may be at risk of becoming extinct from genetic, demographic, or environmental stochasticity or catastrophes in small patches (SHAFFER 1987). Conflict with farmers and poaching of jaguars from local populations could contribute to a source-sink structure (HANSKI \& Simberloff 1997), and destabilize the metapopulation. To summarise, jaguars seem to have the ability to survive and to disperse in marshland habitats. However, their fate could be negatively influenced by frustrated dispersal into cattle ranching environments. Key private inholdings used and identified by these jaguars need to be protected and conservation measures implemented. Management of a healthy population of jaguars in the Upper Paraná River must also focus on maintaining the native marshland community. Large patches of dense and open marshlands interspersed with primary and secondary forests harbor sizable populations of important jaguar prey such as capybaras (Hydrochoerus hydrochaeris Linnaeus, 1766), peccaries (Tayassu pecari Link, 1795 and T. tajacu Linnaeus, 1758) and marsh deer (B. dichotomus).
Our results demonstrate that jaguars use areas without marshlands less often than expected based on availability. Jaguars were especially dependent upon marshland habitats, even when these habitats were rare in the landscape, as demonstrated for the Morro do Diabo region. In managing the remaining landscape we recommend that habitat alteration should not reduce the size of marshland patches below the mean jaguar home range observed in this study area, with observed yearly 95\% home ranges of $18-471 \mathrm{~km}^{2}$. Marshland and forest parches larger than this should also provide space and habitat for dispersing jaguars in this highly fragmented landscape. One of the most important findings is the importance of the marshlands as critical habitat for jaguars. The Upper Paraná River has already lost over $60 \%$ of its open and dense marshlands due to the impacts of drainage projects for rice and sugar cane plantations, cattle ranching, and hydroelectric dams. If the small protected areas, such as the ones already existing in the Upper Paraná region are to sustain jaguar populations, they must include and protect as much of these marshlands as possible, so that jaguars can disperse, hunt wild prey and take care of their cubs without being disturbed. What is urgently needed in these jaguar protected areas is the creation of larger protected areas that can sustain jaguars in their favored habitat.

\section{ACKNOWLEDGEMENTS}

We thank Richard Bodmer for supervising part of this study and Paulo De Marco Jr for help in the statistics. This study was funded by a number of grants. The first grant for the field research was given by the Boticario Foundation in Brazil. Next in order of approval was the Scott Neotropical Fund of the Lincoln Park Zoological Society, The Species Survival Fund from Wildlife Trust, IdeaWild Grant Program, World Wildlife Fund/US, DICE Small Grant Program, The Liz Claiborne Art Ortenberg Foundation, The Ashoka Foundation, Conservation, Food and Health Foundation, 100\% Fund from Fauna and Flora International, The Woodland Park Zoo, The Whitley Awards, The Rolex Awards, The Rufford Small Grant Program and Ridgeway Trust. CAPES provided a scholarship during the PhD studies of the first author. Institutional support was also provided by Companhia Energética de São Paulo, IBAMA, and Instituto Florestal de São Paulo during field studies in Morro do Diabo State Park, and by SEMA- Mato Grosso do Sul, during the field work in Ivinhema State Park.

\section{LITERATURE CITED}

Aв'SABer, A.N. 1977. Os domínios morfoclimáticos da América do Sul. Geomorfologia 52: 1-23.

AEbischer, N.J. \& P.A. RoberTson. 1992. Practical aspects of compositional analysis as applied to pheasant habitat utilization, p. 285-293. In: I.G. PRIEDE \& S.M. SwIFT (Eds).Wildlife telemetry: remote monitoring and tracking of animals. Chichester, Ellis Horwood, 354p. 
Aebischer, N.J; P.A. Robertson \& E.R. Kenward. 1993. Compositional analysis of habitat use from animal radio-tracking data. Ecology 74: 1313-1325.

Aitchison, J. 1986. The statistical analysis of compositional data. London, Chapman and Hall, 286p.

Azevedo, F. 2008. Food habits and livestock depredation of sympatric jaguars and pumas in the Igua"ßu National Park area, south Brazil. Biotropica 40: 494-500.

AкÇAKAYA, H.R. 2004. Using models for species conservation and management: an introduction, p. 3-14. In: H.R. АKÇAKAYA; M.A. Burgman; O. Kindvall; C.C. Wood; P, SJogren-Gulve; J.S. Hatfield, J.S. \& P. McCarthy (Eds). Species Conservation and Management, Case Studies. New York, Oxford University Press.

BEIER, P. 1993. Determining minimum habitat areas and habitat corridors for cougars. Conservation Biology 94: 97-108.

BisBaL, F.J. 1986. Distribution and habitat association of the carnivore community in Venezuela, p. 339-362. In: K.H. Redford \& J.F Eisenberg (Eds). Advances in Neotropical Mammalogy. Gainesville, Sanshill Crane Press, 445p.

Cavalcanti, S.M.C. \& E.M. Gese. 2009. Spatial ecology and social interactions of jaguars (Panthera onca) in the southern Pantanal, Brazil. Journal of Mammalogy 90: 935-945.

Cavalcanti, S.M.C. \& E.M. Gese. 2010. Kill rates and predation patterns of jaguars (Panthera onca) in the southern Pantanal, Brazil. Journal of Mammalogy 91 (3):722-736.

Colchero, F; D. Conde; C. Manterola; C. Chávez; A. Rivera \& G. Ceballos. 2011. Jaguars on the move: Modeling movement to mitigate fragmentation from road expansion in the Mayan Forest. Animal Conservation 14: 158-166.

Coppolillo, P.; H. Gomez; F. Maisels \& R. Wallace. 2004. Selection criteria for suites of landscape species as a basis for sitebased conservation. Biological Conservation 115: 419-430.

Crawshaw JR, P.G. 2004. Uma perspectiva sobre a depredação de animais domésticos por grandes felinos no Brasil. Natureza e Conservação 1: 7-11.

Crawshaw Jr, P.G. \& H.B. Quigley. 1991. Jaguar spacing, activity and habitat use in a seasonally flooded environment in Brazil. Journal of Zoology 223: 357-370.

Crawshaw Jr, P.G.; J.K. Mahler; C. Indrusiak; S.M.C. Cavalcanti; M.R.P.L. Leite \& K.M. SiLvius. 2004. Ecology and conservation of the jaguar (Panthera onca) in Iguacú National Park, p. 271285. In: K.M. Silvius; R.B. Bodmer \& J.M.V Fragoso (Eds). People in Nature: Wildlife Conservation in South and Central America. New York, University of Columbia Press, 430p.

Cullen, L.; R.E. Bodmer \& C. Valladares-Padua. 2001. Ecological consequences of hunting in Atlantic forest patches, São Paulo, Brazil. Oryx 35: 137-144.

Cullen, L.; K.C. Abreu; D.A. SAnA \& A.F.D. Nava. 2005. Jaguars as landscape detectives for the Upper Paraná River corridor, Brazil. Natureza e Conservação 3: 43-58.

Durant, S.M. 1998. Competition refuges and coexistence: and example from Serengeti carnivores. Journal of Animal Ecology 67: 370-386.
Gomez, J.J; A.C. Gozzi; D.W. Macdonald; E. Gallo; D. Centrón \& M.H. Cassini. 2010. Interactions of exotic and native carnivores in an ecotone, the coast of the Beagle Channel, Argentina. Polar Biology 4: 1-8.

Guggisberg, C.A.W. 1975. Cats of the World. New York, Taplinger Publications, 465p.

Haag, T; A.S. Santos; D.S. Sana; R.G. Morato; L. Cullen; P.G. Crawshaw; C. De Angelo; M. Di Bitetti; F.M. Salzano \& E.Eizirik, E. 2010. The effect of habitat fragmentation on the genetic structure of a top predator: loss of diversity and high differentiation among remnant populations of Atlantic Forest jaguars (Panthera onca). Molecular Ecology 19: 49064921.

Haines, A.M.; M.E. Tewes; L.L. LaAck; J.S. Horne \& J.H. Young. 2006. A habitat-based population viability analysis for the ocelots (Leopardus pardalis) in the United States. Biological Conservation 132: 424-436.

Hanski, I.A. \& D. Simberloff. 1997. The metapopulation approach, its history, conceptual domain and application to conservation, p. 5-26 In: I.A. HANSKI \& M.E. Gilpin (Eds) Metapopulation Biology, Ecology, Genetics and Evolution. San Diego, Academic Press, 365p.

Hoogesteijn, R. \& A. Hoogesteijn. 2008. Conflicts between cattle ranching and large predators in Venezuela: Could use of water buffalo facilitate felid conservation? Oryx 42: 132-138

Ivlev, V.S. 1961. Experimental ecology of the feeding of fishes. New Haven, Yale University Press, 220p.

Johnson, D.H.1980. The comparison of usage and availability measurement for evaluation of resource preference. Ecology 61: 65-71.

Karanth, K.; A. Gopalaswamy; N. Kumar; S. Vaidyanathan; J. Nichols $\&$ D. Mackenzie. 2011. Monitoring carnivore populations at the landscape scale: Occupancy modeling of tigers from sign surveys. Journal of Applied Ecology 48: 1048-1056.

Logan, K.A. \& L.L. Irwin. 1985. Mountain lion habitats in the Big Horn Mountains, Wyoming. Wildlife Society Bulletin 13: 257-262.

Mandolfi, E. \& R. Hoogesteijn. 1986. Notes on the Biology and Status of the Jaguar in Venezuela, p.78-89. In: S.D. Miller \& D.D. Everett (Eds). Cats of the World: Biology, Conservation, and Management. Washington, D.C., National Wildlife Federation, 578p.

Miller, F.W. 1930. Notes on Some Mammals from Southern Mato Grosso. Journal of Mammalogy 11: 10-22.

Mourão, G.M. \& Z. Campos. 1995. Survey of broad-snouted caiman (Caiman latirostris) marsh deer (Blastocerus dichotomus) and capybara (Hydrochaeris hydrochaeris) in the area to be inundated by Porto Primavera Dam, Brazil. Biological Conservation 73: 27-31.

Palomares, F.; P. Ferreras; J. Fedriani \& M. Delibes. 1996. Spatial relationships between Iberian lynx and other carnivores in an area of south-western Spain. Journal of Applied Ecology 33: 5-13. 
PInder, L. 1996. Marsh deer population estimate in the Paraná River, Brazil. Biological Conservation 75: 87-91.

Polisar, J.; I. Maxit; D. Scognamillo; L. Farrell; M.E. Sunquist \& J.F. EISENBERG. 2003. Jaguars, pumas, their prey base and cattle ranching: ecological interpretations of a management problem. Biological Conservation 109: 297-310.

Perry, R. 1970. The world of the jaguar. New York, Taplinger Publ. Co., 256p.

Quigley, H.B. \& P.G. Crawshaw JR. 1992. A conservation plan for the jaguar (Panthera onca) in the Pantanal region of Brazil. Biological Conservation 61: 149-157.

RetTiE, J.W. \& P.D. McLoughlin.1999. Overcoming radiotelemetry bias in habitat selection studies. Canadian Journal of Zoology 77: 1175-1184.

Rabinowitz, A. \& B.G. Nottinghan Jr. 1986. Ecology and behaviour of the jaguar (Panthera onca) in Belize, Central America. Journal of Zoology 210: 149-159.

Ribeiro, M.C.; J.P. Metzger; A.C. Martensen; F.J. Ponzoni \& M.M. Hirota. 2009. The Brazilian Atlantic Forest: How much is left, and how is the remaining forest distributed? Implications for conservation. Biological Conservation 142: 1141-1153.

Roosevelt, T. 1914. Thought the Brazilian wilderness. New York, Charles Scribner's Sons, 432p.
Sollmann, R.; M.M. Furtado; H. Hofer; A.T. JÁcomo; N.M. Tôrres \& Silveira, L. 2012. Using occupancy models to investigate space partitioning between two sympatric large predators, the jaguar and puma in central Brazil. Mammalian Biology 77: 41-46.

SHAFFER, M.1987. Minimum viable populations: coping with uncertainty, p. 69-86. In: M.E. Soule (Ed.). Viable Populations for Conservation. Cambridge, Cambridge University Press, 432p.

Schaller, G.B. \& J.M.C. VAsconcelos. 1978. Jaguar predation on capybara. Zeitschrift Fur Saugetierkunde-International Journal of Mammalian Biology 43: 296-301.

Sunquist, M.E.; K.U. Karanth \& F.C. Sunquist. 1999. Ecology, behavior and resilience of the tiger and its conservation needs, p. 5-18. In: J. Seidensticker; S. Christie, P. \& P. Jackson (Eds). Riding the Tiger: Tiger Conservation in Humandominated Landscapes. Cambridge, Cambridge University Press, 763p.

Weckel, M; W. Giuliano \& S. Silver. 2006. Jaguar (Panthera onca) feeding ecology: distribution of predator and prey through time and space. Journal of Zoology 270: 25-30.

Williams, J.S.; J.J. MCCARTHY \& H.D. PICTON.1995. Cougar habitat use and food habits on the Montana Rocky Mountain Front. Intermountain Journal of Sciences 1:16-28.

Submitted: 04.IX.2012; Accepted: 15.V.2013.

Editorial responsibility: Fernando de C. Passos 